\title{
TSG vanaf 2019: online only en open access
}

\author{
Lydia Nieuwendijk
}

(C) Bohn Stafleu van Loghum is een imprint van Springer Media B.V., onderdeel van Springer Nature 2018

Het nummer dat voor $\mathrm{u}$ ligt is het laatste nummer van TSG dat in print wordt uitgegeven. Met ingang van 2019 verschijnt TSG alleen digitaal (online only) via www.springerlink.com, het platform van SpringerNature, waar Bohn Stafleu van Loghum deel van uitmaakt.

TSG was natuurlijk al online beschikbaar. De abstracts van de artikelen zijn voor iedereen te lezen. Medewerkers van instellingen die een abonnement hebben op SpringerLink kunnen de artikelen volledig lezen en downloaden. Het aantal downloads is aanzienlijk en stijgt jaarlijks. Dit alles, gecombineerd met een toenemende vraag van auteurs om hun artikel open access te kunnen publiceren, heeft tot het besluit geleid om met ingang van 2019 het abonnement op de printversie te stoppen en over te gaan naar een volledig open acces-online only tijdschrift.

Met veel genoegen zien redactie en uitgever het aantal aangeboden manuscripten stijgen. Daarnaast worden waardevolle themanummers ontwikkeld onder aanvoering van speciaal samengestelde redactieteams. TSG wordt nu dus een podium waar wetenschappelijke informatie vrij gedeeld wordt en voor iedereen toegankelijk is - en blijft de schakel tussen wetenschap en praktijk.

De uitgever, Lydia Nieuwendijk 